\title{
LOCALITY AND DATE OF COLLECTION OF THE TYPE SPECIMEN OF THE SLATE-COLORED FOX SPARROW
}

\author{
W. ROSS SILCOCK, 6810 Tournament Drive, Houston, Texas 77069; silcock@ \\ rosssilcock.com
}

It has been generally accepted that the type specimen of the Slate-colored Fox Sparrow (Passerella iliaca schistacea Baird, 1858), preserved in the U.S. National Museum of Natural History as USNM A 5718, was collected 19 July 1856 in southwestern Nebraska (AOU 1910, 1931, 1957, Deignan 1961). Questions regarding the locality of collection persist, however, primarily because it is in short-grass prairie (Kaul and Rolfsmeier 1983) some $370 \mathrm{~km}$ east of the nearest known sites of breeding in the Medicine Bow Mountains of southeastern Wyoming (Faulkner 2010; www. eBird.org, species map accessed January 2021). The stage of molt of the adult female specimen (Swarth 1920, Pyle 1997) suggests a date later than mid-July or a different collection location. Mid-July significantly precedes the Fox Sparrow's usual time of fall migration in September and October. There have been no records documented by specimen or photograph of this taxon in Nebraska in the ensuing 160+ years (Silcock and Jorgensen 2020); the nearest such records are along the Front Range of eastern Colorado during migration (eBird.org, accessed January 2021). Finally, questions have been raised (Swarth 1920, Goetzmann 1959, Moore 1986, Wright 2019) about the accuracy of the record as presented by Baird et al. (1858). Here I address these questions in more detail.

The specimen was collected by W. S. Wood, a rod man with a party of the Corps of Topographical Engineers of the U.S. Army. The party was under the command of Lieut. F. T. Bryan during a survey to locate a practicable route for a road between Fort Riley, Kansas, and Bridger's Pass, Wyoming (Baird et al. 1858, Bryan 1945, Jackson 1949, Goetzmann 1959). There is no question that the party was in southwestern Nebraska on 19 July 1856 (Bryan 1945), the purported date of collection.

However, further examination of the route taken by the Bryan party shows that from 7 to 25 August 1856 it camped for several nights in or near the Fox Sparrow's breeding habitat in the northern Medicine Bow Mountains (Table 1). At $2380 \mathrm{~m}$ elevation the 9-10 August campsite was the Bryan party's highest in the northern Medicine Bow Mountains and possibly the only one at an elevation where $P$. $i$. schistacea breeds. Although no subsequent specimens of the Fox Sparrow from the Medicine Bow Mountains are recorded in the collections searchable through www. vertnet.org, there are at www.ebird.org (accessed February 2021) five recent sightings reported as P. i. schistacea at similar elevations $(2250-2400 \mathrm{~m})$ in the northern Medicine Bow Mountains. Two birds were at Rock Creek Access $\left(41.626^{\circ} \mathrm{N},-106.166^{\circ}\right.$ W) on 1 July 2020 (T. Leukering and K. M. Dunning; recording), one was at Brush Creek Ranch $\left(41.360^{\circ} \mathrm{N},-106.543^{\circ} \mathrm{W}\right)$ on 13 July 2020 (K. M. Dunning), one was at Little Laramie Crossing $\left(41.295^{\circ} \mathrm{N},-106.035^{\circ} \mathrm{W}\right)$ on 13 July 2020 (K. M. Dunning),

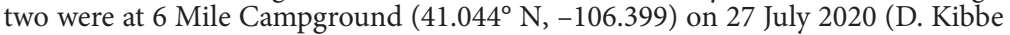
and M. Goldthwait), and two (one singing) were at Rock Creek Canyon (41.580 $\mathrm{N},-106.231^{\circ} \mathrm{W}$ ) on 30 August 2015 (C. Porter). Furthermore, some 20 additional June-July eBird records of the Fox Sparrow for the same region undoubtedly also represent $P$. i. schistacea.

Although the 9-10 August campsite may have been the only one at an elevation where $P$. $i$. schistacea breeds, in fall this subspecies moves downslope from higher altitudes and then migrates (Weckstein et al. 2002). This possibility suggests that any of the sites where the Bryan party camped during the outward trip 7-12 August 
TABLE 1 Approximate Locations and Elevations of Bryan Party Campsites in and near the Northern Medicine Bow Mountains, Wyoming, 7-25 August $1856^{a}$

\begin{tabular}{|c|c|c|c|}
\hline Date & Location $^{b}$ & Coordinates $^{c}$ & Elevation $^{d}$ \\
\hline 7-8 Aug & $\begin{array}{l}\text { West branch Medicine Bow River, near } \\
\text { town of Elk Mountain }\end{array}$ & $\begin{array}{l}41.702 \\
-106.397\end{array}$ & 2190 \\
\hline 9-10 Aug & $\begin{array}{l}\text { Divide between Elk Mountain and } \\
\text { Medicine Bow mountains to the south } \\
\text { along Pass Creek Road }\end{array}$ & $\begin{array}{l}41.596 \\
-106.474\end{array}$ & 2380 \\
\hline 11 Aug & On Pass Creek, west of Elk Mountain & $\begin{array}{l}41.588 \\
-106.715\end{array}$ & 2130 \\
\hline 12 Aug & On North Platte River, near Saratoga & $\begin{array}{c}41.535 \\
-106.885\end{array}$ & 2040 \\
\hline 18-21 Aug & $\begin{array}{l}\text { On North Platte River, north of } \\
12 \text { Aug campsite }\end{array}$ & $\begin{array}{c}41.582 \\
-106.953\end{array}$ & 2040 \\
\hline 22 Aug & On Pass Creek, near 11 Aug campsite & $\begin{array}{l}41.588 \\
-106.715\end{array}$ & 2130 \\
\hline 23-24 Aug & $\begin{array}{l}\text { On Rattlesnake Pass Road north of } \\
\text { Elk Mountain, on Rattlesnake Creek }\end{array}$ & $\begin{array}{l}41.694 \\
-106.547\end{array}$ & 2290 \\
\hline 25 Aug & $\begin{array}{l}\text { Near 7-8 Aug campsite near town of } \\
\text { Elk Mountain }\end{array}$ & $\begin{array}{l}41.702, \\
-106.397\end{array}$ & 2190 \\
\hline
\end{tabular}

${ }^{a}$ As determined from Bryan (1945).

${ }^{b}$ By reference to current towns and highways.

${ }^{c}$ In decimal degrees north latitude and west longitude.

${ }^{d}$ In meters above sea level.

(four sites) or the return trip 18-25 August (four sites) may have been collecting locations (Table 1). Furthermore, Wood may have made collecting trips higher into the nearby mountains from any of the two-night campsites listed in Table 1, and even quite likely from the four-night campsite of 18-21 August on the North Platte River. Intriguingly, if the specimen was collected 19 August on a trip from this camp, one might conclude that "19 July" was written on the specimen's label inadvertently and that at least the location given by Baird et al. (1958) as "head of the Platte" may have been in fact correct.

The specimen was described by Swarth (1920) as an adult female in "badly molting condition." According to Pyle (1997:579), the prebasic molt of adult Fox Sparrows is complete, occurring on the breeding grounds from July to September.

The timing of the Fox Sparrow's fall migration in this region can be ascertained by examining data from the Colorado Front Range at eBird. In this source, as of January 2021, there were 10 records during fall migration along the east edge of the Front Range in northeastern Colorado, all from 24 September to 24 October, except for one on 6 September.

The information discussed above provides considerable support that the type of $P$. i. schistacea was in fact collected in the northern Medicine Bow Mountains in Wyoming between 7 and 25 August 1856 rather than in Nebraska on 19 July 1856 and suggests the specimen may have been mislabeled.

I thank Douglas L. Faulkner and M. Ralph Browning for their important and constructive comments that improved the paper immeasurably. I thank Christopher Milensky for providing photographs of the type of $P$. $i$. schistacea and the relevant pages of the museum catalog. Also, Thomas Labedz for pushing the alternative narrative over the years, Rick Wright for inspiring this research, and Shari Schwartz for research and graphics assistance. 


\section{NOTES}

\section{LITERATURE CITED}

American Ornithologists' Union. 1910. Check-list of North American Birds, 3rd ed. Am. Ornithol. Union, New York.

American Ornithologists' Union. 1931. Check-list of North American Birds, 4th ed. Am. Ornithol. Union, New York.

American Ornithologists' Union. 1957. Check-list of North American Birds, 5th ed. Port City Press, Baltimore.

Baird, S. F., Cassin, J., and Lawrence, G. N. 1858. Reports of explorations and surveys to ascertain the most practible [sic] and economic route for a railroad from the Mississippi River to the Pacific Ocean [etc.], vol. 9. A. O. P. Nicholson, Washington, DC.

Bryan, F. 1945. Report of Lieut. F. T. Bryan concerning his operations in locating a practicable road between Fort Riley to Bridger's Pass 1856. Annals of Wyoming 17:24-55.

Deignan, H. G. 1961. Type specimens of birds in the United States National Museum. U.S. Natl. Mus. Bull. 221; doi.org/10.5479/si.03629236.221.

Faulkner, D. W. 2010. Birds of Wyoming. Roberts and Co., Greenwood Village, CO.

Goetzmann, W. H. 1959. Army Exploration in the American West 1803-1863. Univ. Nebr. Press, Lincoln.

Jackson, W. T. 1949. The Army Engineers as road surveyors and builders in Kansas and Nebraska, 1854-1858. Kansas Historical Quarterly 17:37-59.

Kaul, R. B., and Rolfsmeier, S. B. 1983. Native vegetation of Nebraska (map). Conservation and Survey Div., Univ. of Nebr., Lincoln.

Moore, J. A. 1986. Zoology of the Pacific Railroad Surveys. Am. Zool. 26:331-341; doi.org/10.1093/icb/26.2.331.

Pyle, P. 1997. Identification Guide to North American Birds, part I, Columbidae to Ploceidae. Slate Creek Press, Bolinas, CA.

Silcock, W. R., and Jorgensen, J. G. 2020. Fox Sparrow (Passerella iliaca), in Birds of Nebraska-Online; www.BirdsofNebraska.org.

Swarth, H. S. 1920. Revision of the avian genus Passerella with special reference to the distribution and migration of the races in California. Univ. Calif. Publ. Zool. 21:75-224.

Weckstein, J. D., Kroodsma, D. E., and Faucett, R. C. 2002. Fox Sparrow (Passerella iliaca), in Birds of North America (A. F. Poole and F. B. Gill, eds.), no. 715. Birds N. Am., Inc., Philadelphia; doi.org/10.2173/bow.foxspa.01.

Wright, R. 2019. Sparrows of North America. Houghton Mifflin Harcourt, Boston. 